\title{
Community wireless network development in Ciudad Bolívar
}

\section{Desarrollo de una red inalámbrica comunitaria en Ciudad Bolívar}

\section{Luis F. Pedraza}

Ingeniero Electrónico, magíster en Ciencias de la Información y las Comunicaciones, estudiante de doctorado en Ingeniería de Sistemas y Computación de la Universidad Nacional de Colombia. Docente e investigador de la Universidad Distrital Francisco José de Caldas. Bogotá, Colombia.

Contacto:lfpedrazam@udistrital.edu.co

\section{Andrea Cepeda Ruiz}

Trabajadora Social, especialista en Derecho de Familia. Contratista de la Universidad Distrital Francisco José de Caldas. Bogotá, Colombia.

Contacto: acepedar@udistrital.edu.co

\section{Dora Ballesteros}

Ingeniera Electrónica, magister en Ingeniería Electrónica y de Computadores. Docente de la Universidad Militar Nueva Granada. Bogotá, Colombia.

Contacto:dora.ballesteros@unimilitar.edu.co

Key words: community wireless network, ICT, mesh topology.

Palabras clave: red inalámbrica comunitaria, TIC, topología mesh.

\section{ABSTRACT}

The present paper illustrates the process of fully deploying a wireless network for the local community at Ciudad Bolívar (Bolivar wireless), an outer-city area with the highest poverty levels in Bogotá (Colombia). This paper shows implementation procedures and design stages for the nodes of the community wireless network.
A mesh-based network topology and various Information and Communication Technology (ICT) applications are utilized. These applications are currently being used by the local community due to the service coverage now provided by the community wireless nodes. The performance of the nodes is evaluated and recommendations are provided. Conclusions are drawn in the final part of the paper. 


\section{investigación}

\section{RESUMEN}

En este artículo se expone el proceso llevado a cabo para la realización de la red inalámbrica comunitaria de la localidad Ciudad Bolívar (Bolivar wireless), que es una de las zonas con mayores índices de pobreza en BogotáColombia. Se expone la manera como se diseñaron e implementaron los nodos de la red inalámbrica comunitaria basados en topología en malla y varias aplicaciones de Tecnologías de la Información y las Comunicaciones (TIC), que son actualmente usadas por la comunidad beneficiada, con la cobertura de los nodos de la red inalámbrica en la localidad. Luego, se evalúan los nodos implementados y, finalmente, se presenta las conclusiones y recomendaciones.

\section{INTRODUCTION}

Nowadays, and throughout the past five decades, the permanent emergence of new (and enhanced) technologies has changed mankind's perception of geographical space in terms of both its social and economic connotations, which in turn has also encouraged a redefinition of people's priorities. Global connectivity of the entire world constitutes irrefutable evidence of this claim; in fact, all intentions, ideas or innovations of any kind tend to converge on connectivity.

The use of ICT is no longer associated with technological curiosity but with essential tools that help to build a nation's development. This reflection is founded on a report issued by the United Nations that shows a strong correlation between poverty and the number of ICT users in different countries [1]. Then it can be deduced that the coexistence of generalized poverty and ICT unequal access poses a major threat to social and economic development as well as to prosperity and stability of a nation. In this context, having a communications infrastructure is of vital importance in providing people with connectivity through ICT applications so as to satisfy some of their basic needs.

Because communications (immediate) future appears to be wireless, wireless solutions repre- sent an alternative to democratize the access to communication services, reducing barriers and providing diversity, quality and affordable prices to users. Hence, Wireless Mesh Networks (WMNs) appear as one of the key technologies that will prevail over other wireless networks in the next decade [2]. This will make dreams come true regarding long-lasting, simple, lowcost connections anywhere at any time. Consequently, this kind of networks will play a key role in the development of Internet's next generation. Functionalities such as self-organization will significantly reduce network implementation complexity as well as network maintenance; therefore, this networking concept requires minimal initial investment [3], which is highly important in low-income communities like Ciudad Bolívar.

Modern laws on the use of free spectrum bands (like $2.4 \mathrm{GHz}$ ) together with their corresponding technologies (like WMNs) make it possible to think about the possibility of creating a vehicle for research, expression, information and, in general, for public welfare. Such vehicle would represent an asset for users, universities, research groups, emergency services, information services, etc, and would also allow the development of new contents and also of personal communication systems; in general, it would allow the construction of a true information society. 


\section{RELATED WORK}

This section presents some of the community wireless network projects that proved to be feasible and sustainable in the long term. These projects were also adaptable to context-specific conditions and fulfilled community needs such as education, security, health, social development, economic growth and cultural development among others.

In [4], the development of a community network in Nepal is described. The purpose of such a network was to expand a Wi-Fi network to unreachable and isolated geographical areas. In 2008 there was Internet connection availability at community centers, schools and hospitals in 42 villages. The most remarkable services offered by this network are as follows: Internet access, e-mail, telephone calls, e-education, telemedicine and financial transactions.

In [5] the development of a wireless community network in Wray (England) is presented. In this Project, the University of Lancaster together with some community members started the implementation of a WMN to cover the whole town. The project allowed villagers to access broadband services for the first time and also gave researchers the opportunity to analyze processes and technical challenges associated to the deployment and operation of an actual mesh network.

The wireless mesh network in use by the Dharamsala community began in February 2005 after WiFi regulations in India adopted the results from a series of tests that proved mesh topology was the most suitable technology for such a mountainous region; unlike conventional point-to-point networks where line-of-sight limitations could not be overcome. Ciudad Bolivar shares this particular geographic situation. In Chile, there is also an organization called Chilesincables.org, which promotes and organizes free wireless networks through the use of open-code technologies [6].
AWMN (Athens Wireless Metropolitan Network) for Athens in Greece is also based on Mesh topology. Currently, this network has over 2000 nodes and offers different services such as VoIP, video streaming, game servers, websites, and web hosting [7].

\section{METHODOLOGY}

This section presents all factors involved when designing and implementing the wireless community network. Some of the factors include Bolivar wireless coverage estimations, wireless-nodes structure, a web site, applications development, and community training to make good use of the network resources.

\subsection{Community Wireless Network Design}

In order to calculate the coverage of both the uplinks and downlinks of every node, the following expressions were applied in equation (1)

$$
P_{r x \mid d B m}=P_{\left.t x\right|_{d B m}}+G_{t d B i}-L_{\left.p\right|_{d B}}-\left.M D\right|_{d B}
$$

Where:

$P_{r x}=$ reception power.

$P_{t x}=$ transmission power.

$G_{t}=$ link total gain.

$L_{p}=$ link total loss.

$M D=$ design margin.

In order to find an appropriate design margin over the client-to-router link, reception power analysis was considered at different points on the network, as show in figure 1. 


\section{investigación}

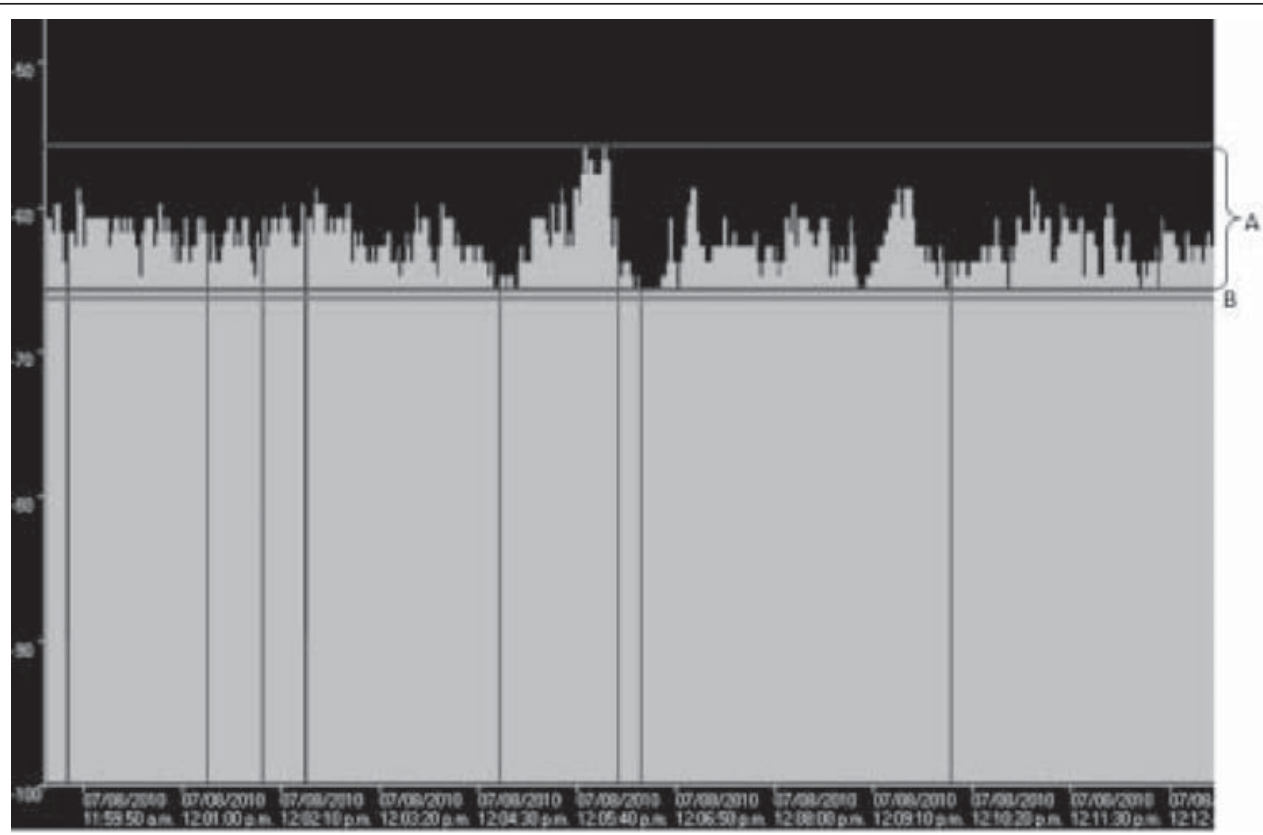

Figure 1. Reception power variation at a point on the wireless

Source: own work.

In figure 1 , the line associated to letter B indicates the sensitivity level on the receiver. The lines associated to the letter A denote a variation interval for the reception power; from this variation, MD can be obtained to guarantee greater link availability. In figure 1 , the line associated to letter B indicates the sensitivity level on the receiver. The lines associated to the letter A denote a variation interval for the reception power; from this variation, $M D$ can be obtained to guarantee greater link availability equation (2).

$$
M D=P_{r x(\max )}-P_{r x(\min )}
$$

$P_{t x}$ corresponds to the router being used for the downlink together with the wireless adapter (wireless card) for the uplink. $G_{t}$ is determined by the gain summation of all antennas, which correspond to the router's omnidirectional antenna and also to the home-made antenna that is connected to the adapter on the user's computer (wireless card). $L_{p}$ is determined by considering the summation of the following losses, measured at the points where links provide their widest coverage (between $300 \mathrm{~m}$ and $600 \mathrm{~m}$ depending on the obstacles between transmitter and receiver).

$L_{c}=$ losses on connetors $(0.2 \mathrm{~dB}$ at each connector - taken from data sheet)

$L_{g}=$ pigtail cable loss $(0.6 \mathrm{~dB}$ per meter - taken from data sheet)

$L_{p d}=$ discharge-protection loss $(0.2 \mathrm{~dB}-$ taken from data sheet)

$L_{o}=$ propagation losses caused by the environment

Finding $L_{o}$ depends on the conditions of the terrain where the wireless node is operating. The locality's mountainous conditions lead to the use of propagation models such as Xia-Bertoni [8] provided there is non-line-of-sight (NLOS) 
Table 1. Minimum average reception power for each node

\begin{tabular}{|c|l|c|}
\hline $\begin{array}{c}\text { No. } \\
\text { nodo }\end{array}$ & Nombre del nodo & $\mathrm{P}_{\mathrm{Rx}} \min (\mathrm{dBm})$ \\
\hline 1 & Los Alpes & $-60,21$ \\
\hline 2 & Barrio Bella Flor & $-64,47$ \\
\hline 3 & Ispa Potosí & $-76,59$ \\
\hline 4 & Barrio La Estrella & $-73,12$ \\
\hline 5 & Jerusalén Canteras & $-61,34$ \\
\hline 6 & Ispa Jerusalén & $-74,89$ \\
\hline 7 & Fundación Bella Flor & $-65,09$ \\
\hline 8 & Taller de Mis Sueños & $-60,13$ \\
\hline 9 & Arborizadora Baja & $-72,65$ \\
\hline 10 & Paraíso Mirador sede A & $-57,26$ \\
\hline 11 & Paraíso Mirador sede B & $-70,67$ \\
\hline
\end{tabular}

Source: own work.

between client and router; and also a free-spaceloss model [9] whenever there is line-of-sight (LOS).

From equation (1) and equation (2), and considering that average reception power should exceed router sensitivity, $-97 \mathrm{dBm}$ at the lowest connection speed in this particular case (1 Mbps), table 1 shows the minimum average reception power guaranteed within each node's maximum coverage.

On the other hand, it is essential to find Fresnel's first zone in order to calculate pole heights for both the router and the home-made antenna, since a free-of-obstacle trajectory guarantees proper propagation of the signals allowing adequate connectivity.

Figure 2 shows the location of the eleven nodes described in table 1. Most of the nodes are located in public schools facilities in the locality (Ciudad Bolívar).

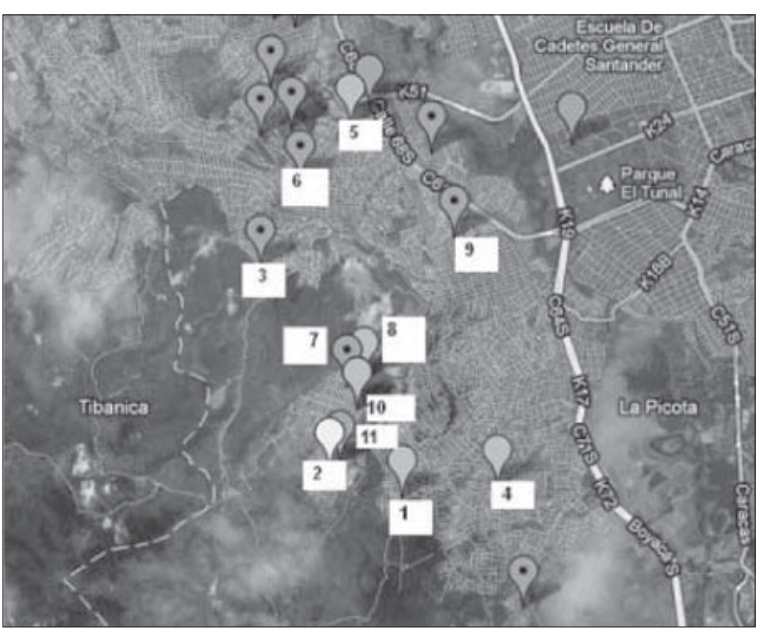

Figure 2. Community wireless network nodes at Ciudad Bolívar

Source: own work.

\subsection{Wireless-nodes traffic estimation}

Regarding link capacity, the average number of users supported by the community wireless node is calculated as follows equation (3).

$$
L=N-\frac{\mu}{\lambda}\left(1-P_{0}\right)
$$

Where, $\mathrm{N}$ is maximum number of users, $\lambda$ is arrival rate, $\mu$ is service rate and $\mathrm{P}_{0}$ is the probability that the system is empty. Table 2 shows the

Table 2. Number of average users on each node under poor connection conditions

\begin{tabular}{|c|l|c|}
\hline $\begin{array}{c}\text { No. } \\
\text { nodo }\end{array}$ & Nombre del nodo & $\begin{array}{c}\text { No. aprox. de } \\
\text { usuarios }\end{array}$ \\
\hline 1 & Los Alpes & 13 \\
\hline 2 & Barrio Bella Flor & 9 \\
\hline 3 & Ispa Potosí & 11 \\
\hline 4 & Barrio La Estrella & 10 \\
\hline 5 & Jerusalén Canteras & 13 \\
\hline 6 & Ispa Jerusalén & 12 \\
\hline 7 & Fundación Bella Flor & 10 \\
\hline 8 & Taller de Mis Sueños & 11 \\
\hline 9 & Arborizadora Baja & 13 \\
\hline 10 & Paraíso Mirador sede A & 13 \\
\hline 11 & Paraíso Mirador sede B & 9 \\
\hline
\end{tabular}

Source: own work. 


\section{investigación}

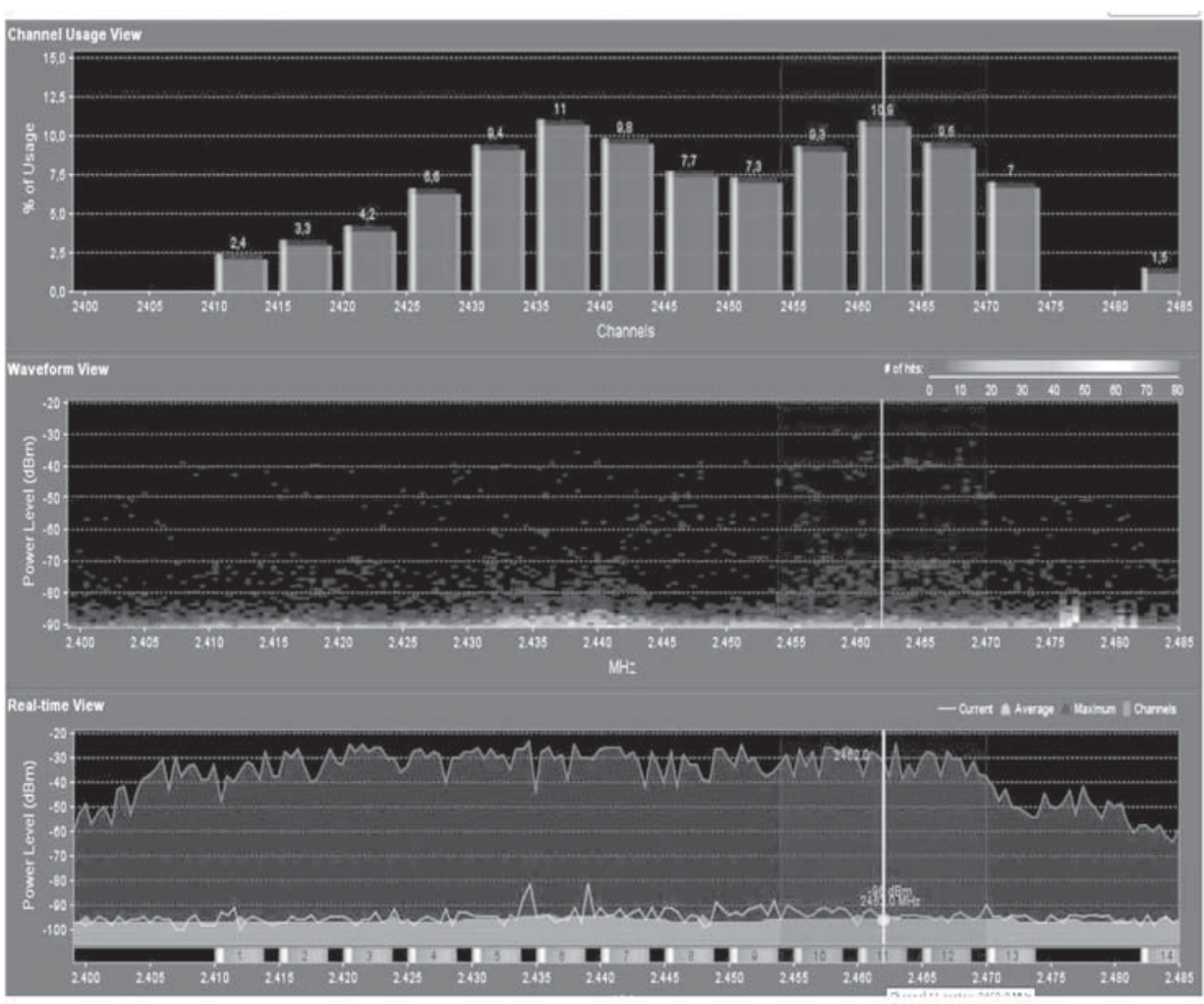

Figure 3. Channel measurement within the $2.4 \mathrm{GHz}$ band using a spectrum analyzer on the wireless network nodes Source: own work.

average number of users that might be served by each node under the worst conditions, that is, when users are located at the farthest coverage point where the connection bandwidth is $1 \mathrm{Mbps}$. Additionally, since the web applications installed on each node require about $100 \mathrm{Kbps}$ to operate, equation (3) can be used so as to find the approximate number of users supported by each node according to its web applications, which in the worst-case scenario is equivalent to:

\subsection{Interference analysis on the network channels}

In order to choose the appropriate channel to be used by the wireless-node routers, within 2.4 $\mathrm{GHz}$ band, interference and channel occupancy measurements were carried out around the node's coverage area. Figure 3 shows one of the 55 mea-
Table 3. Channel average occupancy percentage within the $2.4 \mathrm{GHz}$ band for the community wireless network nodes at Ciudad Bolívar

\begin{tabular}{|c|c|}
\hline Canal & Porcentaje promedio de ocupación \\
\hline 1 & $4,2 \%$ \\
\hline 2 & $5,6 \%$ \\
\hline 3 & $7,9 \%$ \\
\hline 4 & $14,2 \%$ \\
\hline 5 & $17,4 \%$ \\
\hline 6 & $23,7 \%$ \\
\hline 7 & $21,1 \%$ \\
\hline 8 & $13 \%$ \\
\hline 9 & $14,5 \%$ \\
\hline 10 & $15,4 \%$ \\
\hline 11 & $21,7 \%$ \\
\hline 12 & $17,3 \%$ \\
\hline 13 & $12,4 \%$ \\
\hline 14 & $4,8 \%$ \\
\hline
\end{tabular}

Source: own work. 


\section{investigación}

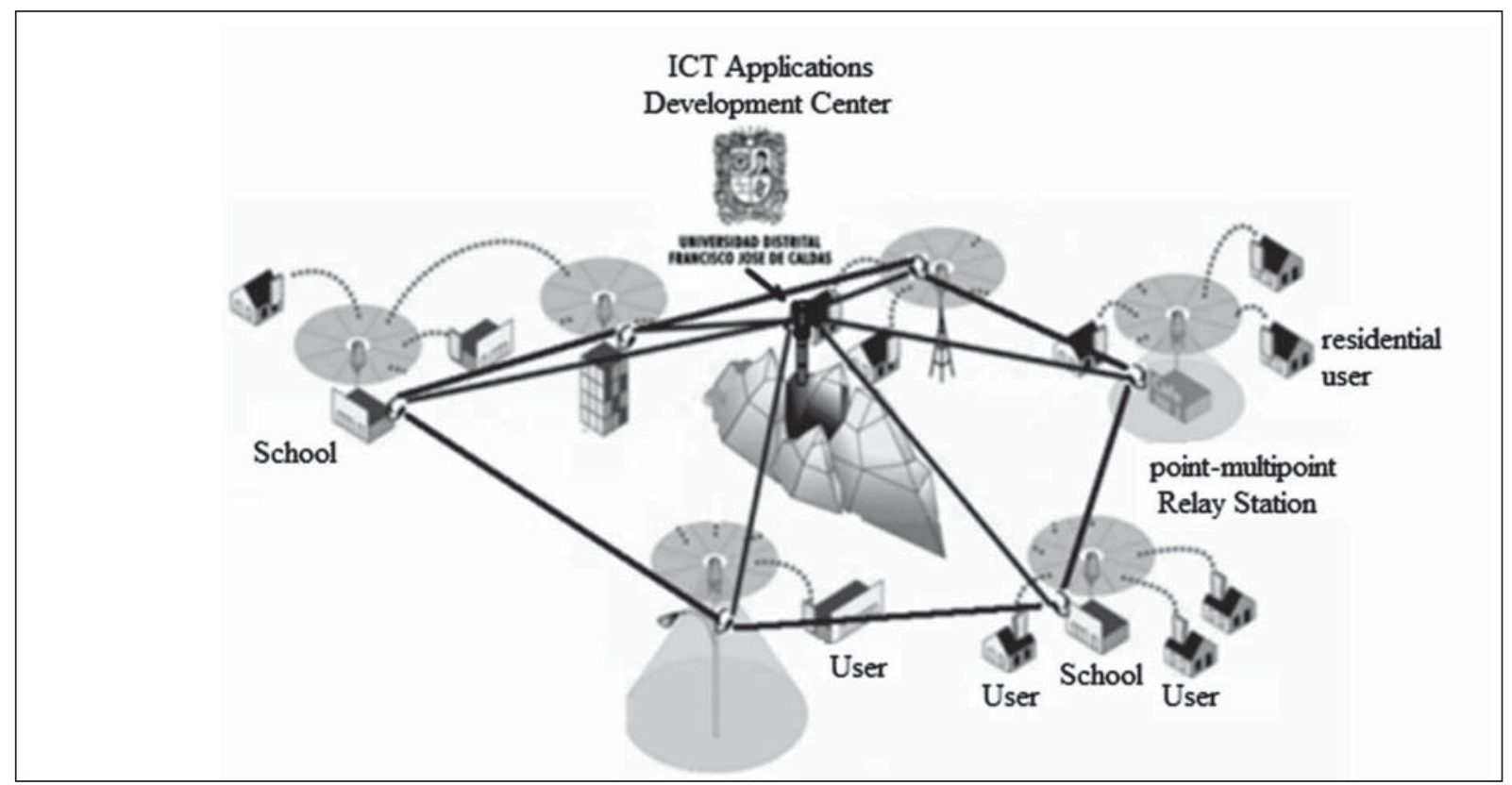

Figure 4. Interconnection proposal for the community wireless network nodes at Ciudad Bolívar Source: own work.

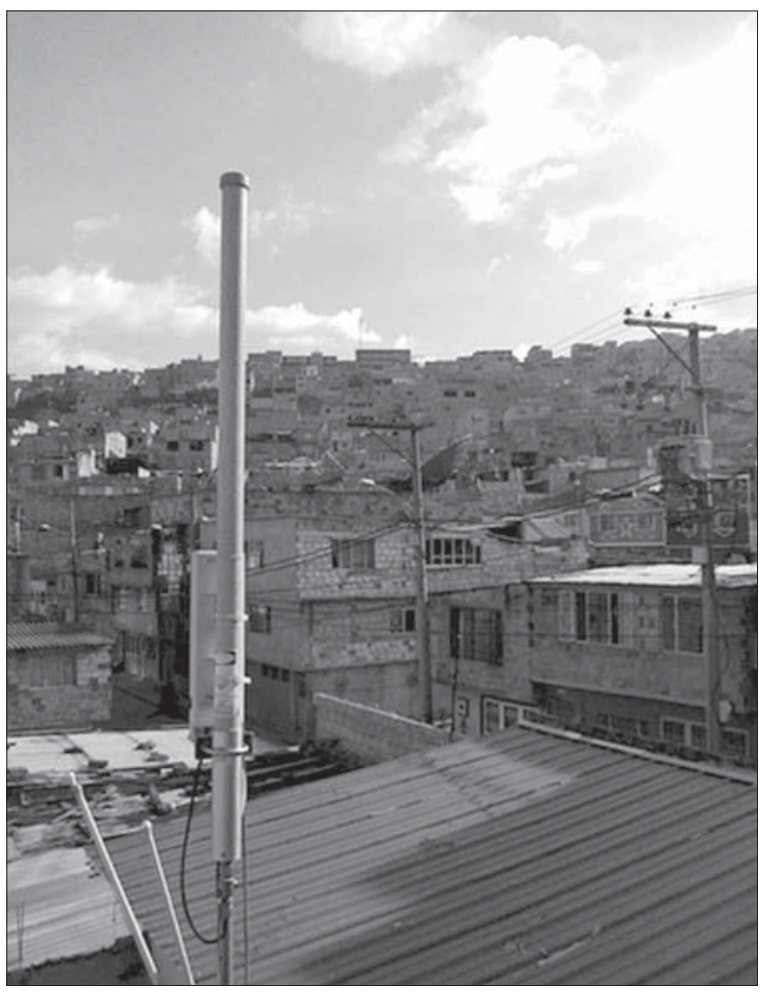

Figure 5. A Bolivar wireless implemented node Source: own work. surements. Table 3 shows the occupancy percentage average obtained for every of the 14 channels within the area covered by the 11 nodes, which allowed selecting channel 1 as the least occupied. It can be observed that channels 2 and 3, which overlap slightly with channel 1 , also present low occupancy percentages. This allows improving users access stability and, consequently, higher data transfer speed over the community network.

\subsection{Description of the nodes implemented}

Figure 4 presents the proposed interconnection for the development of the community wireless network at Ciudad Bolívar, which is expected to be connected to the ICT Applications Development Center (CDATICS) in the near future. The Center is located in the facilities of Facultad Tecnológica (Universidad Distrital).

Figure 5 shows one of the nodes implemented to provide coverage to the community at Ciudad 


\section{investigación}

Bolívar through Bolivar wireless. The components involved in the external implementation of the wireless nodes are basically the following:

- Nanostation 2 Access point.

- Omnidirectional antenna with $15 \mathrm{dBi}$ gain.

- Electrical discharge protector.

- Pigtail cable to connect the access point to the omnidirectional antenna.

- Pole.

Nodes, like the one shown above (figure 5), had a captive portal previously developed and installed. The node's firmware also had the routing protocol called B.A.T.M.A.N [10] installed.

\section{RESULTS AND EVALUATION}

The wireless nodes of the community network at Ciudad Bolívar were evaluated in terms of their coverage; reception power and transfer speeds were considered. Approximately 5 measurements were carried out at different distances.

The results shown in table 4 were obtained after taking various measurements of the received power and calculating the average of 5 samples at each point for every node.

From table 4, it can be observed that the received power levels are appropriate for external links. In order to guarantee adequate network coverage inside users households, most of the times it is necessary to use home-made antennas like the one shown in figure 6 . In the table 5. Potencia de Recepción promedio para evaluar cobertura

Download-speed data at every point are presented in table 5. It can be observed that download speed fluctuates between 2 and $291 \mathrm{Kbps}$. When compared with table 4, these data suggest that, in general, the points where there is higher reception power present higher download speed resulting from the adaptive modulation scheme.

\subsection{Applications developed and implemented over the network}

Based on the analysis of the survey conducted [11] and also on the community needs that were identified in the node's surrounding areas, different applications were developed for the inhabitants that have access to the network. Among the

Table 4. Average reception power for every node

\begin{tabular}{|c|l|c|c|c|c|c|}
\hline $\begin{array}{c}\text { No. } \\
\text { nodo }\end{array}$ & Nombre & $\begin{array}{c}\text { PRx a } 100 \mathrm{~m} \\
(\mathrm{dBm})\end{array}$ & $\begin{array}{c}\mathrm{PRx} \text { a 200 m } \\
(\mathrm{dBm})\end{array}$ & $\begin{array}{c}\text { PRx a 300 m } \\
(\mathrm{dBm})\end{array}$ & $\begin{array}{c}\text { PRx a 350 m } \\
(\mathrm{dBm})\end{array}$ & $\begin{array}{c}\text { PRx a 400 m } \\
(\mathrm{dBm})\end{array}$ \\
\hline 1 & Los Alpes & -42 & -55 & -63 & -83 & -90 \\
\hline 2 & Barrio Bella Flor & -47 & -60 & -65 & -78 & -85 \\
\hline 3 & Ispa Potosí & -40 & -54 & -67 & -81 & -92 \\
\hline 4 & Barrio La Estrella & -50 & -51 & -72 & -74 & -80 \\
\hline 5 & Jerusalén Canteras & -43 & -54 & -53 & -65 & -78 \\
\hline 6 & Ispa Jerusalén & -50 & -48 & -70 & -77 & -84 \\
\hline 7 & Fundación Bella Flor & -41 & -50 & -68 & -73 & -92 \\
\hline 8 & Taller de Mis Sueños & -46 & -57 & -64 & -69 & -85 \\
\hline 9 & Arborizadora Baja & -42 & -48 & -77 & -83 & -95 \\
\hline 10 & Paraíso Mirador sede A & -44 & -53 & -79 & -74 & -91 \\
\hline 11 & Paraíso Mirador sede B & -41 & -49 & -57 & -75 & -78 \\
\hline
\end{tabular}

Source: own work. 


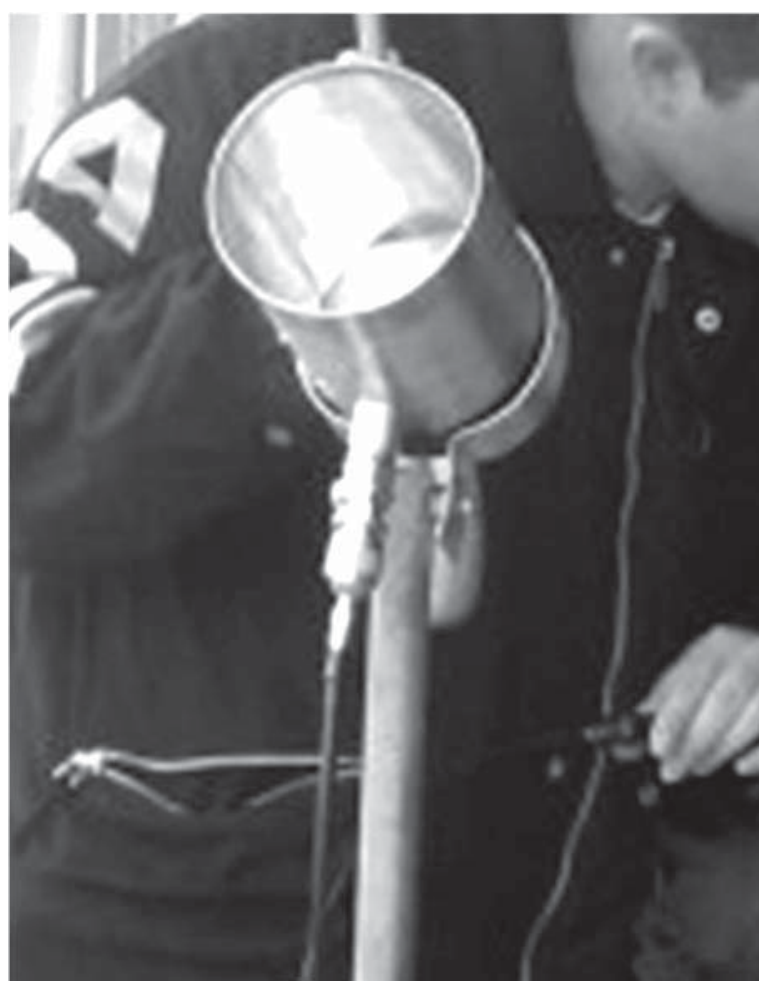

Figure 6. Home-made antenna developed for the Bolivar wireless project

Source: own work. open-software-based web services implemented on this community wireless network, the most representative are: wikipedia, chat, virtual radio station, e-marketing platform [12], games, blogs, accounting courses and computer science courses among others.

At each of the nodes locations, there has been permanent community training to ensure the appropriate use of the wireless network resources. In the context of such training scheme, the community learnt how to use the multiple applications available at the wireless nodes in an efficient way through services such as chat, virtual radio station, forums, wikipedia, e-learning and other services provided by the platform. The point was to help users exploit the network resources by making proper use of the applications, which offer entertainment and education that contributes to improve the quality of life of every community member. This approach brings information technologies closer to this area of the city, where the rates of technological illiteracy are considerable.

Table 5. Average download speeds for different distances from the nodes

\begin{tabular}{|c|c|c|c|c|c|c|}
\hline $\begin{array}{l}\text { No. } \\
\text { nodo }\end{array}$ & Nombre & $\begin{array}{l}\text { Velocidad a } \\
100 \mathrm{~m} \text { (Kbps) }\end{array}$ & $\begin{array}{l}\text { Velocidad a } \\
200 \mathrm{~m} \text { (Kbps) }\end{array}$ & $\begin{array}{l}\text { Velocidad a } \\
300 \mathrm{~m} \text { (Kbps) }\end{array}$ & $\begin{array}{l}\text { Velocidad a } \\
350 \mathrm{~m} \text { (Kbps) }\end{array}$ & $\begin{array}{c}\text { Velocidad a } \\
400 \mathrm{~m} \text { (Kbps) }\end{array}$ \\
\hline 1 & Los Alpes & 268 & 134 & 89 & 30 & 12 \\
\hline 2 & Barrio Bella Flor & 180 & 176 & 83 & 41 & 23 \\
\hline 3 & Ispa Potosí & 114 & 89 & 57 & 35 & 2 \\
\hline 4 & Barrio La Estrella & 236 & 185 & 139 & 92 & 45 \\
\hline 5 & Jerusalén Canteras & 156 & 73 & 71 & 34 & 8 \\
\hline 6 & Ispa Jerusalén & 169 & 123 & 78 & 56 & 12 \\
\hline 7 & Fundación Bella Flor & 111 & 86 & 62 & 33 & 15 \\
\hline 8 & Taller de Mis Sueños & 291 & 213 & 181 & 123 & 100 \\
\hline 9 & Arborizadora Baja & 189 & 134 & 79 & 68 & 5 \\
\hline 10 & Paraíso Mirador sede A & 213 & 146 & 130 & 142 & 66 \\
\hline 11 & Paraíso Mirador sede B & 215 & 131 & 77 & 64 & 13 \\
\hline
\end{tabular}

Source: own work. 


\section{investigación}

\section{CONCLUSIONS}

A free-access wireless network was successfully deployed in the locality of Bogotá called Ciudad Bolívar. The network offers different services that facilitate information access to all inhabitants of the surrounding area through ICT applications. Similarly, by working with non-profit and public organizations it was possible to promote wireless connectivity at Ciudad Bolívar in order to serve the community.

A web page that shows the network status was created. Participation in this web page occurs through forums, which offer a virtual meeting place for all users interested in the development of the network itself. Research-wise, communi- cation-wise and entertainment-wise applications for the community were also promoted.

Home-made antennas at the location of the community wireless-network users allowed wider network coverage, up to $40 \%$ wider.

It is necessary that non-profit organizations such as Universidad Distrital continue to lead this kind of social initiatives that allow massive network access throughout the entire locality since the nodes implemented in the present work represent only the starting point and, most importantly, set an example to other institutions that may contribute to reduce the so called "digital divide" in this locality.

\section{REFERENCIAS}

[1] United Nations Conference on Trade and Development, Information Economy Report, ICTs Enterprises and Poverty Alleviation, Geneva and New York, 2010.

[2] L. Pedraza, "Redes Inalámbricas de bajo costo, aporte a la minimización de la brecha digital", in V Congreso de Electrónica, Control y Telecomunicaciones, Universidad Distrital, Bogotá Colombia, 2009.

[3] I. F. Akyildiz and X. Wang, "Wireless Mesh Networks", John Wiley Publishing Company, February 2009.

[4] A. Abdelaal, H. Ali, "Community Wireless Networks: Emerging Wireless Commons for Digital Inclusion", in The International Symposium on Technology and Society (ISTAS'09), Tempe, Arizona, USA, 2009.

[5] J. Ishmael, S. Bury, P. Dimitrios and N. Race, "Deploying Rural Community Wire- less Mesh Networks", IEEE Internet Computing, Vol. 12. No. 4. 2008. pp. 22-29.

[6] R. Flickenger, C. Fonda, J. Forster, I. Howard, T. Krag, et al., (2008), Wireless Networking in the Developing World. 2nd Ed, [Online] Available: http://wndw.net/

[7] F. Elianos, G. Plakia, P. Frangoudis, G. Polyzos, et al., "Structure and Evolution of A Large-Scale Wireless Community Network", Proc. 10thIEEE Int'l. Symp. Worldof Wireless, Mobile and Multimedia Networks (WoWMoM 2009), Kos, Greece, 2009.

[8] H. Xia and L. Bertoni, "Diffraction of Cylindrical and Plane Waves by an Array of Absorbing Half-Screens", IEEE Transactions on Antennas and Propagation, Vol. 40, No. 2. 1992.

[9] J. Seybold, Introduction to RF Propagation, Wiley Publishers, New Jersey, USA, 2005. 
[10] D. Murray, M. W. Dixon and T. Koziniec, "An experimental comparison of routing protocols in multi hop ad hoc networks", Australasian Telecommunication Networks and Applications Conference, ATNAC, 2010.

[11] G. Mancilla, L. Pedraza, R. Niño y D. Laverde, Medición de la situación de partida de acceso uso y apropiación de las TICs por parte de hogares de la localidad de Ciudad Bolivar, [Tech Report.] Bogotá, Colombia, 2010.

[12] L. F. Pedraza; R. Ramírez García; O. E. Hernández, "Diseño e implementación de una plataforma piloto de marketing electrónico para el desarrollo de aplicaciones TICs en la comunidad de Ciudad Bolívar", Tecnura, Vol. 15, No. 28, pp. 42-52, junio 2011. 